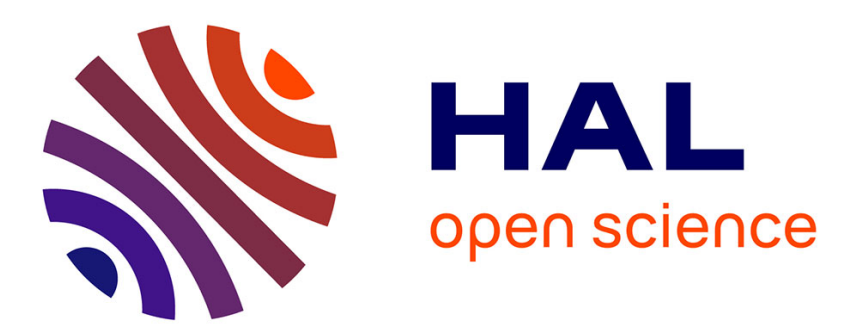

\title{
Towards an Ecosystem Approach to Assess the Impacts of Marine Renewable Energy
}

Jean-Philippe Pezy, Aurore Raoux, Nathalie Niquil, Jean-Claude Dauvin

\section{To cite this version:}

Jean-Philippe Pezy, Aurore Raoux, Nathalie Niquil, Jean-Claude Dauvin. Towards an Ecosystem Approach to Assess the Impacts of Marine Renewable Energy. Bispo, R.; Bernardino, J.; Coelho, H.; Lino Costa, J. Wind Energy and Wildlife Impacts, Springer International Publishing, pp.153-164, 2019, 978-3-030-05519-6. 10.1007/978-3-030-05520-2_10 . hal-02083947

\section{HAL Id: hal-02083947}

\section{https://hal-normandie-univ.archives-ouvertes.fr/hal-02083947}

Submitted on 29 May 2019

HAL is a multi-disciplinary open access archive for the deposit and dissemination of scientific research documents, whether they are published or not. The documents may come from teaching and research institutions in France or abroad, or from public or private research centers.
L'archive ouverte pluridisciplinaire HAL, est destinée au dépôt et à la diffusion de documents scientifiques de niveau recherche, publiés ou non, émanant des établissements d'enseignement et de recherche français ou étrangers, des laboratoires publics ou privés. 


\title{
Towards an ecosystem approach to assess the impacts of Marine Renewable Energy
}

\author{
Jean-Philippe Pezy ${ }^{*[0000-0002-8293-5090]}$, Aurore Raoux ${ }^{1[0000-0002-4701-7796]}$, Nathalie Niquil ${ }^{2[0000-0002-0772-754]} \&$ \\ Jean-Claude Dauvin ${ }^{10000-0001-8361-5382]}$
}

${ }^{1}$ Normandie Univ, UNICAEN, UNIROUEN, Laboratoire Morphodynamique Continentale et Côtière, CNRS, UMR 6143 M2C, 24 Rue des Tilleuls, 14000 Caen, France

${ }^{2}$ Unité Biologie des Organismes et Ecosystèmes Aquatiques (BOREA), MNHN, CNRS, IRD, Sorbonne Université, Université de Caen Normandie, Université des Antilles, CS 14032, 14000 CAEN, France

E-mail: jean-philippe.pezy@unicaen.fr $\square ;$ aurore.raoux@unicaen.fr; nathalie. niquil@unicaen.fr and jeanclaude.dauvin@unicaen.fr.

\begin{abstract}
The French government has since the beginning of the 2000' the ambition that the offshore wind production formed $40 \%$ of the renewable electricity in 2030, and three calls tenders of Offshore Wind Farms (OWF) construction have been pronounced since 2011. However, no marine wind farm had been constructed at the end of 2017 due to long administrative procedures and numerous appeals in justice, at French and European levels. Nevertheless, several studies have been enterprise to identify the environmental conditions and ecosystem functioning in selected sites before OWF implantations. However, these studies are generally focused on the conservation of some species or groups of species and there is no holistic study on the effects of the construction and operation of OWF on an ecosystem taken as a whole. In 2017, a complete and integrated view of the ecosystem of two future OWF sites of the eastern English Channel (Courseulles-sur-Mer and Dieppe-Le Tréport) were developed to model the marine ecosystems before OWF implementation and to simulate reef effects due to new spatial occupation of maritime territory. Results contribute to a better knowledge of the impacts of the OWFs on the functioning of marine ecosystems. They also allow to define recommendations for environmental managers and industry in terms of monitoring the effects of Marine Renewable Energy (MRE), not only locally, but also on other sites, at national and European levels.
\end{abstract}

Key-words: Offshore wind farm; Ecosystemic approach; Ecopath with Ecosim; Ecological Network Analysis; Monitoring; Benthos; Demersal fish; Suprabenthos 


\section{Introduction}

In the face of global climate change linked to $\mathrm{CO} 2$ emissions, there is a worldwide demand for energy transition and the development of Marine Renewable Energy (MRE) has became a major policy objective [1]. For instance, the European Union (EU) has set a target of $20 \%$ of the energetic consumption to be derived from renewable energy sources by 2020 (Directive 2009/28/EC). In line with these political imperative, MRE sector is growing significantly to allow the energetic transition. Among these MRE, Offshore Wind Farms (OWFs) has seen consistent growth in capacity and it is by far the most technically advanced of all MRE [2]. However, this OWF development has raised concerns about their potential impacts on ecosystems [3]. In fact, the construction of OWF is responsible for change in the surrounding environment and so far, the different ecosystem components (i.e. benthos, fish, and birds) that have been studied have already shown some degree of response to OWF. For instance, OWF will be responsible for the introduction of hard substratum $[4,5]$ which will create new habitats for several benthic and epibenthic species [6]. Thus, OWF may act as artificial reefs due to their foundations and potential scour protections $[6,7]$. At the same time, OWF may also include a local habitat loss or degradation [4]. OWFs that have been built in Europe have been subjected to an Environmental Impact Assessment (EIA) in order to identify both the environmental conditions and ecosystem functioning in selected sites (before OWF construction) and the effects of these new structures on the surrounding marine ecosystems. However, one of the main issue linked to these monitoring programs is that they are focused on the conservation of some species or groups (iconic or flag species) and there is no holistic study on the effects of OWF construction and operation on an ecosystem taken as a whole [7]. Thus, the environmental impacts of OWF construction at the ecosystem scale remain unclear [3].

In France, no OWF have been yet constructed. However, three successive calls for tenders related to OWF development have been successively published and seven sites have been selected for future OWF construction [8, 9]. Following, these calls for tenders, several studies have been enterprise to identify the environmental conditions and ecosystem functioning in selected sites before OWF constructions. In 2017, Raoux et al. [7], Raoux [8] and Pezy [9] explored a new way to look at the potential impacts of OWFs through food-web models and flow analysis. In fact, they developed an ecosystem integrated view of two future OWF sites of the eastern English Channel (Courseulles-sur-Mer and Dieppe-Le Tréport) to describe the marine ecosystems before OWF construction and to simulate reef effect.

In this article, we summarize the present state of art of the offshore renewable energy development in France and more particularly in the eastern English Channel, with a special emphasis on the issues that are hampering its effective implementation. We also present the methodology and the main results of the MRE ecosystem approach developed by Raoux et al. [7], Raoux [8] and Pezy [9]. Finally, we also conclude with the lessons learned from this modelling and with the recommendations for future monitoring programmes that we can derived from it. 


\section{OWF development state-of-the-art}

\subsection{OWF in France}

Renewable energy sources research and development raised a challenge for maritime countries in Europe in the last decades. For more thant fitheen years, OWF have been built accross the Europe [8]. OWF developments were most important in the north European countries (Denmark, Germany, Netherlands, United-Kingdom) than in the south European countries like those around the Mediterranean Sea, where the wind farm had been developed in land (Spain, Greece, Italy). With more than 11 million $\mathrm{km}^{2}$ of waters under its jurisdiction, France holds a huge natural potential for marine renewable energy [8]. At the scale of the Europe the France has the second potential of Offshore Wind Farm (OWF) after the UK. The French government has since the beginning of the 2000' the ambition that the offshore wind production formed $40 \%$ of the renewable electricity in 2030, with to first steps: 500 MW on 31 December 2018, and 3,000 MW on 31 December 2023 (https://www.ecologiquesolidaire.gouv.fr/eolien-en-mer).

Three successive calls for tenders linked to the offshore wind development had been successively published. The first call for tenders was pronounced on 11 July 2011 and concerned five zones for a total production of 3,000 MW: Dieppe-Le Tréport, Fécamp, Courseulles-sur-Mer, Saint-Brieuc and Saint-Nazaire, four of them concerned the English Channel (EC) and three the eastern part of the EC (Fig. 1). The candidates have been selected following three main criteria: the quality of the industrial and social project, the price of the electricity, and the respect of the marine environment and the sea users. Only four candidates had been retained: Fécamp (Seine-Maritime, 498 MW), Courseulles-sur-Mer (Calvados, 450 MW), Saint-Nazaire (Loire-Atlantique, $480 \mathrm{MW}$ ) and Saint-Brieuc (Côtes d'Armor, $500 \mathrm{MW}$ ). After the administrative authorisations and the maritime concessions, the beginning of the production had been estimated to 2020-2021 (ten years of administrative procedures).

The second call was pronounced on 18 March 2013 and concerned two zones: Dieppe-Le Tréport (Seine-Maritime, $500 \mathrm{MW}$ ) and between the Yeu and Noirmoutier islands (Loire-Atlantique, $500 \mathrm{MW}$ ) near the Loire estuary (Fig. $1)$.

The third call published in April 2017 concerned only one site offshore of Dunkerque in the southern part of the North Sea (Fig. 1).

$<$ Figure 1>

At the same time, the French government wants to develop a floating wind turbine sector. A call for projects for the deployment of pre-commercial floating wind farms was launched on 5 August 2015. Four projects were founded of which three are in the Mediterranean Sea and one along the Atlantic coast:

- "Provence Grand Large" project is owned by "Electricité De France Energies Nouvelles" (EDF) EN? and will comprise 3 turbines ( $8 \mathrm{MW}$ );

- "Eoliennes flottantes Golfe du Lion" project is owned by Engie/EDP Renewables/Caisse des Dépôts and will comprise 4 (6 MW) turbines;

- "Eolmed" project is owned by Quadran and will comprise 4 turbines (6 MW);

- "Eoliennes flottantes de Groix" project is owned by Eolfi/CGN (China Guangdong Nuclear power group) and will comprise 4 turbines (6 MW). 
OWF construction follows a regulatory framework based on the maritime public domain (decree $\mathrm{n}^{\circ} 2004-308$ of 29 March 2009), and on the environmental code (article L214-2). Moreover, the General Tax Code (article 519 B) is beneficial for municipalities and sea users, and annual tax on electricity production encourages using mechanical wind energy located offshore (territorial sea). A simplification and consolidation of the offshore wind farm's legal framework was revised in the publication of decree $n^{\circ} 2016-9$. One improvement, for instance, is that the allowance to occupy a maritime public domain was increased from 30 to 40 years.

A guide to assess the environmental impact of the offshore wind farm construction and operation was published in 2010 and is revised each year [8]. This guide takes into account the evolution of methods and knowledge as well as feedback on the operation of OWF. This document aims to support actors in the offshore wind power branch during the EIA. It is targeted at all actors concerned by the OWF development.

The implementation of this infrastructure is a challenge for developers from technical, legal, social, and environmental points of view. Indeed, these OWF will be integrated into ecosystems already subjected to a growing number of anthropogenic disturbances such as pollution, transportation, fishing, aggregate extraction, or sediment dredging and deposit [7, 10-12]. Nevertheless, seven years after the first call, no OWF was constructed in France and probably, if they exist, the construction would begin in 2021

\subsection{OWF in eastern EC}

Four projects raised in the eastern part of the EC, one along UK and three along France. The following paragraphs present the four OWF that have been built or will be built in the future in the eastern EC.

\section{The Rampion OWF}

The Rampion OWF (79 km²; 13 and $25 \mathrm{~km}$ to the coast; $400 \mathrm{MW}$ ) was constructed by E.ON off the Sussex coast in the UK. The construction is expected to be completed in 2018. E.ON's final plans use 116 turbines of approximately 3.45 MW capacities. The project was approved by the UK government in July 2014. An onshore construction work began in June 2015 with construction of a new electricity substation adjacent to the existing National Grid Bolney. The first wind turbine was lifted into place in March 2017, with work to backfill the cable duct trenches off Lancing beach initially due to be completed in Spring 2017. Electricity production is expected to start during the third quarter of 2017. Construction of the wind farm is expected to be completed in 2018 at a cost of $£ 1.3$ billion (https://www.eonenergy.com/). Thus, the delay between the decision and the electricity production in the case of the UK procedure was about four years.

\section{The Courseulles-sur-mer OWF}

The project is owned by "Eoliennes Offshore du Calvados", a subsidiary of Eolien Maritime France and WPD Offshore. The Eolien Maritime France (EMF) was allowed to operate the offshore wind farm off from Courseullessur-Mer by the Ministerial Order of April $18^{\text {th }}$ 2012. The proposed wind farm will be located 10 to $16 \mathrm{~km}$ offshore from the coast of Calvados - Normandy. The wind farm will have a total area of approximately $50 \mathrm{~km}^{2}$. It will comprise 75 turbines (6 MW) giving a combinated nameplate capacity of $450 \mathrm{MW}$. The wind farm turbines will be connected via an interarray network of $33 \mathrm{kV}$ AC cables which will link at one offshore transformer substation 
located within the wind farm. From this station power will be exported via two $225 \mathrm{kV}$ AC marine cables. The turbines are supported by $7 \mathrm{~m}$ of diameter monopiles driven into the sea bed. The foot print of the 75 turbines foundation and of the converter station will be $0.158 \mathrm{~km}^{2}$ or $0.03 \%$ of the overall wind farm area. Our work hypothesis was that scour protections will be installed around the 75 turbines and the converter station and $33 \%$ of the cables will be rock-dumped, thus the foot print would amount to $0.342 \mathrm{~km}^{2}$, or $0.72 \%$ of the OWF area. The production generated by the wind park would cover the average annual electricity consumption of approximately 630,000 people, i.e. around $40 \%$ of the inhabitants of the surrounding region of Normandy. The commissioning would be provided for 2021 .

\section{The Fécamp OWF}

The project is owned by "Eoliennes Offshore de Fécamp", a subsidiary of EMF. The proposed wind farm will be located 13 to $22 \mathrm{~km}$ offshore from Fécamp. The wind farm will have a total area of approximately $67 \mathrm{~km}^{2}$. The wind farm will comprise 83 turbines (6 MW) giving a combined nameplate capacity of $498 \mathrm{MW}$. The foundations correspond to gravity base structures. The wind farm turbines will be connected via an interarray network of 33 $\mathrm{kV}$ AC cables, which will link at one offshore transformer substation located within the wind farm. From this station, power will be exported via two $225 \mathrm{kV}$ AC marine cables. The commissioning would be provided for 2021.

\section{The Dieppe-Le-Tréport OWF}

Following the call of tender launched by the government in March 2013, the Dieppe-Le Tréport offshore wind farm project is owned, the June $3^{\text {rd }} 2014$ by the society «Eoliennes en mer Dieppe-Le Tréport », a subsidiary of ENGIE, EDP Renewables and Caisse des Dépôts whose exclusive supplier is ADWEN (100\% subsidiary of Siemens Gamesa Renewable). The wind farm will be located $15.5 \mathrm{~km}$ offshore Le Tréport and $17 \mathrm{~km}$ offshore Dieppe, in water depths ranging from 12 to $25 \mathrm{~m}$. The project will cover an area of approximately $83 \mathrm{~km}^{2}$, with a total of 62 turbines, each having a capacity of $8 \mathrm{MW}$, giving a combined installed capacity of $496 \mathrm{MW}$. The wind farm turbines will be connected via an interarray network of $33 \mathrm{kV}$ AC cables, which will link at one offshore transformer substation located within the wind farm. From this station, power will be exported via two $225 \mathrm{kV}$ AC marine cables. The foundations correspond to jacket structures. The turbines would be spaced of 1,000 $\mathrm{m}$ in order to favor the fishing. The commissioning would be provided for 2021.

\subsection{Issue Hampering MRE development}

The French government wants to develop OWF activities along its coasts. However, this development is hampered by too many procedures and actions for annulment brought by fisherman and environmental protection associations. For instance, the public inquiry, who had been appointed by the Seine Maritime Prefect, gave a favourable opinion on the construction of the Fécamp OWF on $1^{\text {st }}$ December 2015. However, today the project is still hampered by actions for annulment brought by fisherman on 13 June 2017 who have lodged complaints to the European Commission.

On the same line, the Marine Nature Park "Estuaires Picards et mer d'Opale" (MNP) management board has not given a favourable opinion concerning the Dieppe-Le Tréport OWF construction on the October $20^{\text {th }} 2017$. This decision was reached after careful analysis of the environmental impact assessment. However, it is worth to know 
that this decision is no longer decisive but advisory. Indeed, the final decision belongs to the French Agency for Biodiversity which gave a favorable opinion on the $20^{\text {th }}$ February 2018.

In front of the long delay to the implantation of OWF along the French metropolitan coast, at the end of November 2017, a part of the discourse of the Prime Ministry Edouard Philippe at the 'Assisses de l'économie de la mer', Le Havre concerned the OWF development in France. 'Wind turbines at sea in France; it's mostly for the delay. A delay which, in the country of the Rance tidal plant, made a little mess. A delay that we tried to catch up in 2015. As soon as 2018, we will launch the preliminary studies for the application of future tenders on wind power floating in Brittany and the Mediterranean. We will also launch environmental studies and public debate on the draft wind laid off the coast of Oléron. To better manage future conflicts of use, I have asked the prefects to implement strategic planning and space of the maritime spaces and their copy by summer 2018. I asked to the Environment ministry, a radical simplification of procedures of education work. The goal? Be traced back as early as possible the preliminary, in particular environmental studies. And make them drive by the State. Of course, it is not to deny conflicts of use. The sea belongs to anyone. It belongs to all. But a conflict, it is anticipated, it is defused, it can subside too, thanks to studies of quality and a serious dialogue”.

In addition, the administrative procedures of the French government are not always consistent between the different sites of OWF construction leading to different monitoring strategies. Thus, monitoring surveys will differ from one site to another. This is the case for the Courseulles-sur-mer and the Fécamp OWF sites which are located in the same region (Normandy) and are situated some $100 \mathrm{~km}$ from one another.

For the Courseulles-sur-Mer OWF project, a monitoring committee and a scientific committee are scheduled to be set up under the authority of the Calvados department prefect and maritime prefect. This committee would be composed by the regional fisheries committee, the local communities and scientists. The offshore wind farm consortium will present the environmental monitoring strategy to the committee which will be in charge to analyse and validate it. For the Fécamp offshore wind farm site, a scientific monitoring committee was created under the authority of the department prefect and maritime prefect. This scientific committee relies on the Commission Régionale Mer et Littoral (COMEL), extended to the French Research Institute for the Exploitation of the Sea (Institut Français de Recherche pour l'Exploitation de la MER, IFREMER) and the French Agency for Biodiversity (AFB). The monitoring studies should be also presented to the scientific committee for recommendation before validation.

In the end, pragmatism prevailed in the UK procedures which led to the construction of the Rampion offshore wind farm in four years whereas no OWF have been yet constructed (in seven years) along the French coasts due to many complex procedures. There is an urgent need to simplify the French procedures. One way, would be to have only one operator responsible for the coordination of the OWF construction environmental studies along the French coasts as found in Belgium. For instance, each year the Royal Belgium Institute of Natural Sciences publishes the main scientific findings of the Belgian offshore wind farm monitoring program [13]. These monitoring programs target physical (i.e: hydro-geomorphology), biological (i.e: fish communities, soft substrate macrobenthos, fish communities, hard substrate) and socio-economic aspects [13]. 


\section{An ecosystem approach for Dieppe-Le Tréport and Courseulles-sur-Mer wind farm sites}

\subsection{The Ecopath modelling approach}

In order to gain further knowledge on the ecosystem structure and functioning before the construction of the Dieppe-Le Tréport (DLT) and the Courseulles-sur-Mer OWF, trophic web models describing the initial state of the both sites were built by Pezy [9] and Raoux et al. [7]. They used the software Ecopath with Ecosim (EwE) [14-16] to model the trophic web at the two sites. This approach, in which all biotic components of the system could be considered at the same time, is useful to gain a better understanding of the system trophic structure and functioning, and for predicting how it may change over time when facing perturbations [17]. The proposed model considered the full range of size classes of biota, from prokaryotes to top predators. In addition, this approach also allows to provide measure of the ecosystem emergent properties through the calculation of Ecological Network Analysis indices [18]. More details are given in Raoux et al. [7].

\section{Dieppe-Le Tréport OWF site}

As mentioned below, Pezy [8] built an Ecopath model to describe the initial state of the Dieppe-Le Tréport OWF site. For that the collection of new data on biological compartments (zooplankton, suprabenthos, meiofauna, benthos and demersal fishes) were essential. Four cruises (summers 2014 /2015 and winters 2015 /2016) allowed to estimate the contribution of each zoological group in three main benthic habitats: i.e. sandy Gravels $(\mathrm{sG})$, gravelly Sand (gS) and medium clean Sand (S), founded on the site, corresponding to two benthic communities well represented in the English Channel (Fig. 2). The Zooplankton were sampled with WP2 (200 $\mu$ m) nets in two stations from two benthic habitats (sG and S) with day and night samplings. Benthic macrofauna was sampled with a Van Veen grab $\left(0.1 \mathrm{~m}^{2}\right)$ at 25 stations (with 5 replicates) (Fig. 2). The Suprabenthos was sampled with a modified Macer-Giroq sledge [19] in two stations from two benthic habitats (sG and S) with day and night samplings (Fig. 2). Demersal fish was sampled with a beam trawl (3m) in ten stations. Stomach contents analysis of demersal fish were carried out (Fig. 2). In fact, this analysis allowed to quantify the contribution of benthic preys located in the future implementation site of the offshore wind farm to the diet of demersal fish species and so to identify the benthic species playing a key role in the trophic web. The models were composed by 27 compartments from bacteria to cetacean.

$<$ Figure 2>

\section{Courseulles-sur-Mer OWF site}

On the same line, Raoux et al. [7] ran also the EwE approach to model the trophic web at the site of the construction of the future Courseulles-sur-Mer OWF. Thus an Ecopath ecosystem model composed of 37 compartments, from phytoplankton to seabirds, was built to describe the situation "before" the OWF construction. It was built by using the data collected during the EIA of the Courseulles-sur-Mer (CSM) wind farm site

The Dieppe-Le Tréport and the Courseulles-sur-Mer OWFs share in common a same sedimentary type which is the gravelly Sand. The ecosystem biomasses of the gravelly sand of the both sites (DLT and CSM) are dominated 
by benthic invertebrate filter feeders with a biomass of $45 \mathrm{gC} \cdot \mathrm{m}^{-2}$ at the DLT site (dominated by the bivalves Glycymeris glycymeris and Polititapes rhomboides) and a biomass of $22.5 \mathrm{gC} \cdot \mathrm{m}^{-2}$ at the CSM site (dominated by the bivalve Polititapes rhomboides) (Table 1).

$<$ Table 1>

\subsection{Simulation the "reef effect" due to the wind farm implantation using Ecosim simulations}

As mentioned before, so far, there is no holistic study on the OWF construction and operation effects on an ecosystem taken as a whole. Indeed, EIA have only been investigated on benthic and fish species but no studies have adopted a holistic approach to assess its potential impacts on the ecosystem structure and functioning [7, 8]. Recently, Raoux et al. [7] explored a new way to look at the potential impacts of OWFs through food-web models and flow analysis. In fact, Raoux et al. [7] derived an Ecosim model (the temporal dynamic module of EwE) to project over the next 30 years the ecosystem evolution after the simulated increase in biomass of some targeted benthic and fish compartments in relation to the wind farm construction (i.e. forcing a reef effect). ENA indices [18] were finally calculated, summarising ecosystem functional traits and giving indications about the possible ecosystem state evolutions at the end of the simulation. Among the core conclusions, this modelling approach showed (1) that the total ecosystem activity, the overall system omnivory (proportion of generalist feeders in the system), and the recycling should increase after the construction of the OWF [7], (2) that important higher trophic levels such as exploited piscivorous fish species, endangered marine mammals and seabirds might very likely and positively respond to the aggregation of biomass on piles and turbine scour protections. More details were given in Raoux et al. [7].

\section{Lessons learned and recommendation for the future}

Actually, the EIA consider the sensitivity to potential disruptions of some groups of valuable species without taking into account the links between them [7, 8]. Thus, OWF construction effects on the ecosystem structure and function remain unclear. A more holistic view is needed to allow the passage of the split vision (site by site; activity by activity, country by country) to an ecosystem approach of the English Channel (especially since the species impacted by OWFs are species with large distribution area (i.e, marine mammals and sea birds)) as recommended by the Marine Framework Directive [12]. The holistic view of OWF impacts on the trophic web developed by Raoux et al. [7] through trophic web modelling could be replicated on other site in the English Channel (French and English sides) and could be useful to analyze the reef and reserve long term effects in the context of climate change. Indeed, using quantitative modelling to assess offshore wind farm impacts on the whole ecosystem would allow to bring new knowledge to policy makers. It would also allow for a better integration of ecological considerations in managing decisions, and for planning maritime space.

The vision for an ecosystem-based management for both sides of the EC requires a common vision between France and the UK to adapt the future management of this marine space as climate change and human pressures increase (e.g., granulate extraction and new offshore energies, such as wind farms and hydraulic systems). In the future, studies of the cumulative effects of human pressure [10-11] must be promoted at the level of both the subdivisions proposed, which appears to be a coherent level of ecosystem-based management. However, to date each state 
manages its own side independently. Thus, France and the UK must imagine synergies to jointly manage this maritime area in a Brexit context.

\section{Acknowledgments}

These works were co-funded by the Normandy Region, the group "Eoliennes Offshore du Calvados" and by the group “Eoliennes en mer Dieppe-Le Tréport”. We also acknowledge, for their help in the data sampling, the captain and the crew of the Oceanographic Vessel "Celtic Warrior". We acknowledge the two anonymous reviewers for their comments on this article. 


\section{References}

1. Bergström, L., Sundqvist, F., Bergström, U.: Effects of an offshore wind farm on temporal and spatial patterns in the demersal fish community. Marine Ecology Progress Series 485, 199-210 (2013).

2. Willsteed, E-D., Jude, S., Gill, A., Birchenough, S.N.R.: Obligations and aspirations: A critical evaluation of offshore wind farm cumulative impact assessments. Renewable and Sustainable Energy Reviews 82, 2332-2345 (2018). https://doi.org/10.1016/j.rser.2017.08.079

3. Bailey, H., Brookes, K.L., Thompson, M.: Assessing environmental impacts of offshore wind farms: lessons learned and recommendations for the future. Aquatic Biosystems 10, 1-13(2014). https://doi.org/10.1186/2046-9063-10-8

4. Petersen, J. K., Malm, T.: Offshore windmill farms: threats to or possibilities for the marine environment. Ambio 35, 75-80 (2006). www.jstor.org/stable/4315689

5. De Mesel, I., Kerckhof, F., Norro, A., Rumes, B., Degraer, S.: Succession and seasonal dynamics of the epifauna community on offshore wind farm foundations and their role as stepping stones for non-indigenous species. Hydrobiologia 756, 37-50 (2015).

6. Wilhelmsson, D., Malm, T.: Fouling assemblages on offshore wind power plants and adjacent substrata. Estuarine, Coastal and Shelf Science 79, 459-466 (2008). https://doi.org/10.1016/j.ecss.2008.04.020

7. Raoux, A., Tecchio, S., Pezy, J-P., Degraer, S., Wilhelmsson, D., Cachera, M., Ernande, B., Lassalle, G., Leguen, C., Grangeré, K., Le loch, F., Dauvin, J-C., Niquil, N.: Benthic and fish aggregation inside an offshore wind farm: Which effects on the trophic web functioning? Ecological Indicators 72, 33-46 (2017). https://doi.org/10.1016/j.ecolind.2016.07.037

8. Raoux, A. : Approche écosystémique des Energies Marines Renouvelables: étude de l'impact sur le réseau trophique de la construction du parc éolien au large de Courseulles-sur-Mer et du cumul d'impacts. Thèse de Doctorat, Université de Caen Normandie, France, 293 pp (2017).

9. Pezy, J-P.: Approche écosystémique d'un futur parc éolien en Manche orientale: exemple du site de Dieppe - Le Tréport. Thèse de Doctorat, Université de Caen Normandie, France, 324 pp (2017).

10. Halpern, B.S., Walbridge, S., Selkoe, K.A., Kappel, C.V., Micheli, F., D'Agrosa, C., Bruno, J.F., Casey, K.S., Ebert, C., Fox, H.E., Fujita, R., Heinemann, D., Lenihan, H.S., Madin, E.M.P., Perry, M.T., Selig, E.R., Spalding, M.D., Steneck, R., Watson, R.: A global map of human impact on marine ecosystems. Science 319, 948-952 (2008). doi: 10.1126/science.1149345 11. Halpern, B. S., K. L. McLeod, A. A. Rosenberg, and L. B. Crowder.: Managing for cumulative impacts in ecosystem-based management through ocean zoning. Ocean Coastal Management 51, 203-211(2008). https://doi.org/10.1016/j.ocecoaman.2007.08.002

12. Dauvin, J-C.: Are the eastern and western basins of theEnglish Channel two separate ecosystems? Marine Pollution Bulletin 64, 463-471 (2012). https://doi.org/10.1016/j.marpolbul.2011.12.010

13. Degraer, S., Brabant, R., Rumes, B., Vigin, L.: Environmental impacts of offshore wind farms in the Belgium part of the North Sea: a continued move towards integration and quantification. Brussels: Royal Belgium Institute of Ntural Sciences, OD Natural Environment, Marine Ecology and Management Section, 141 pp (2017).

14. Polovina, J-J.: Model of a coral reef ecosystem. The ECOPATH model and its application to French Frigate Shoals. Coral Reefs 3, 1-11 (1984)

15. Christensen, V., Walters, C.J.: Ecopath with Ecosim: methods, capabilities and limitations. Ecological Modelling 172, 109139 (2004). https://doi.org/10.1016/j.ecolmodel.2003.09.003

16. Christensen, V., Walters, C.J., Pauly, D., Forrest, R.: Ecopath with Ecosim version 6 User Guide. Lensfest Ocean Futures Project 2008 1-235 (2008).

17. Plagànyi, E.E.: Models for an ecosystem approach to fisheries. FAO Fisheries Technical Paper, Vol. 477. FAO, Rome. 108 pp (2007).

18. Ulanowicz, R. E.: Growth and Development: Ecosystems Phenomenology. SpringerVerlag, New York. 166 pp (1986).

19. Dauvin, J.C., Lorgeré, J.C.: Modifications du traîneau MACER-GIROQ pour l'amélioration de l'échantillonnage quantitatif étagé de la faune suprabenthique. Journal de recherche océanographique 14, 65-67 (1989). 
Figure captions

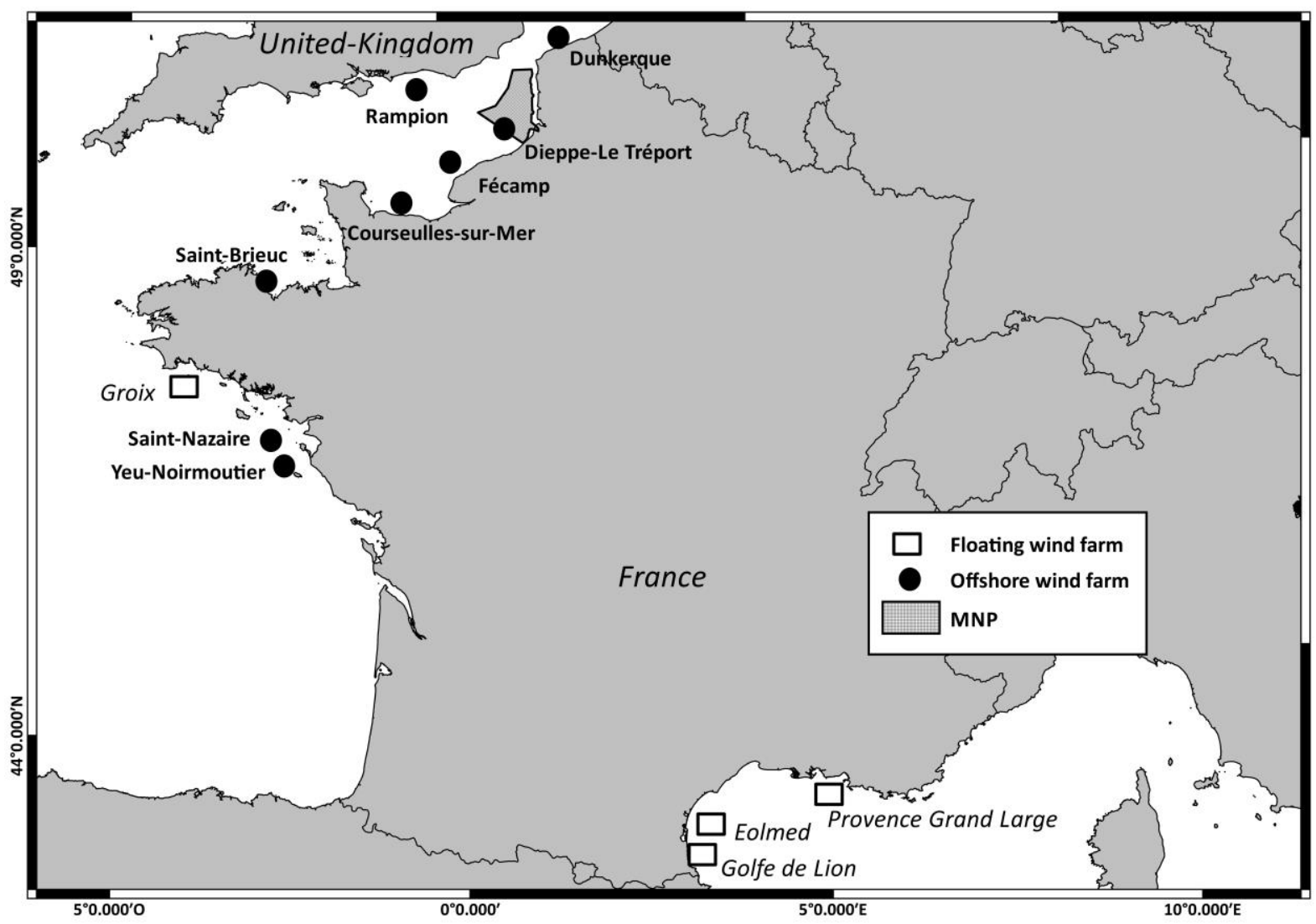

Fig. 1. Map of the French offshore wind farm development 


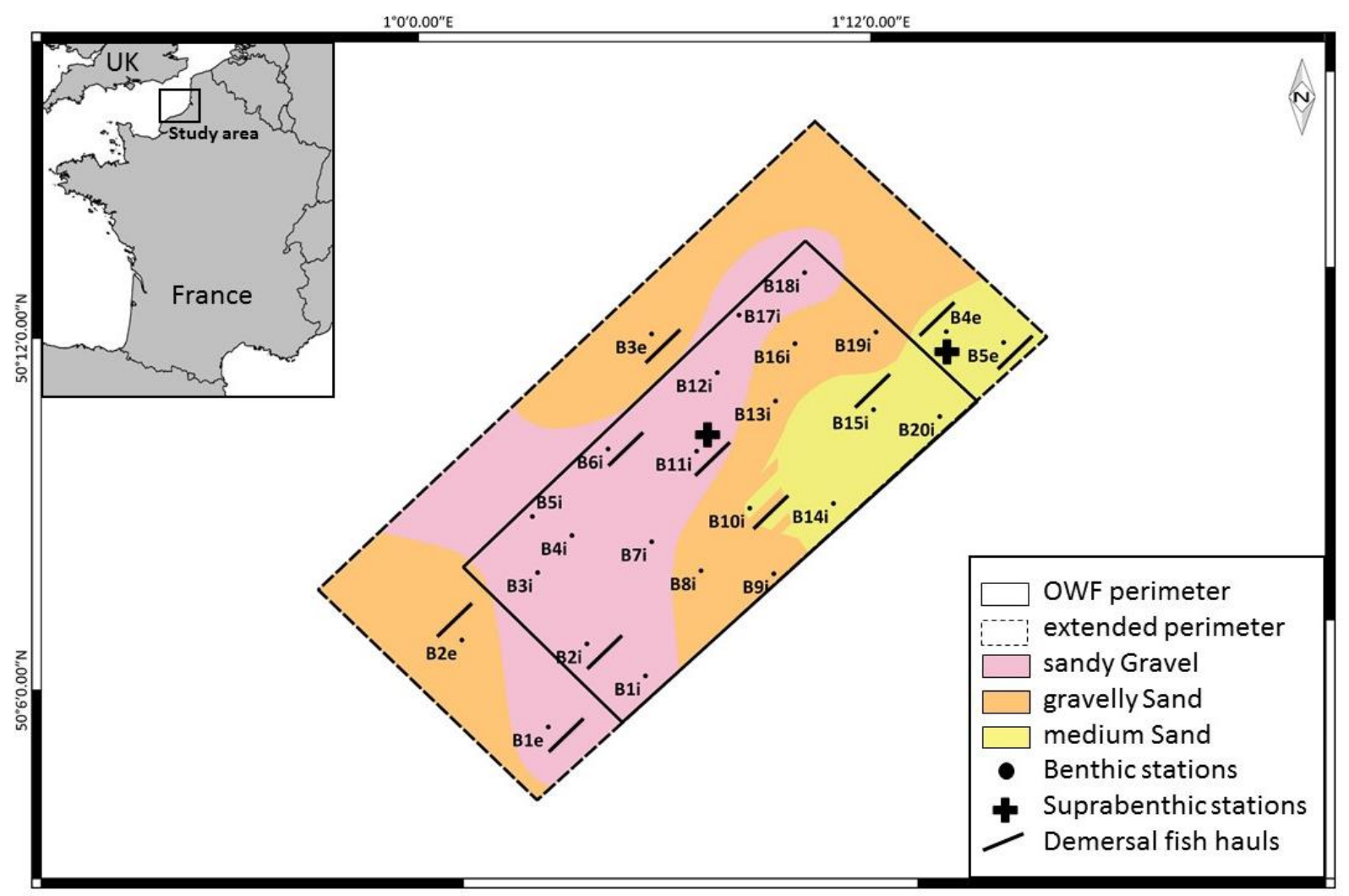

Fig. 2. Localisation of the different compartment samples (benthos, suprabenthos, and demersal fish) at the Dieppe-Le-Tréport site 
Table 1. Biomass $\left(\mathrm{gC} \cdot \mathrm{m}^{-2}\right)$ of the different compartments of the two sites. (DLT: Dieppe-Le Tréport; CSM: Courseulles-sur-Mer).

\begin{tabular}{|c|c|c|}
\hline & \multicolumn{2}{|c|}{ Biomass (gC.m-2) } \\
\hline & DLT & CSM \\
\hline Fish piscivorous & 0.02 & 0.28 \\
\hline Fish planktivorous & 0.62 & 1.16 \\
\hline Fish. benthos feeders & 0.007 & 3.16 \\
\hline Fish flatfish & 0.02 & 0.08 \\
\hline Benthic invertebrate. Predators & 1.08 & 2.93 \\
\hline Benthic invertebrate. Filter feeders & 46.49 & 23.42 \\
\hline Benthic invertebrate. Deposit feeders & 4.86 & 3.54 \\
\hline Meiofauna & 1.67 & 0.97 \\
\hline Suprabenthos & 0.56 & 2.00 \\
\hline Zooplankton & 0.61 & 1.72 \\
\hline Phytoplankton & 3.10 & 3.24 \\
\hline Bacteria & 0.75 & 0.75 \\
\hline
\end{tabular}

